\title{
PEMBERDAYAAN KOPERASI, USAHA MIKRO, KECIL DAN MENENGAH (UMKM) MELALUI LEMBAGA KEUANGAN SYARIAH (LKS) UNTUK MENGENTASKAN KEMISKINAN DAN PENGURANGAN PENGANGGURAN
}

\author{
Djawahir Hejazziey \\ Fakultas Syariah dan Hukum Jakarta \\ Jl. Ir. H. Juanda 95, Ciputat, Jakarta.
}

\begin{abstract}
Abstrak: Upaya pengembangan koperasi dan UMKM melalaui LKS pada dasarnya memerlukan langkah-langkah taktis dan strategis berupa peningkatan visi dan misi bisnis yang sesuai syariah Islam, sehingga tercipta SDM yang islami dan berkualitas. Guna pengintegrasian pengembangan Koperasi dan UMKM dengan lembaga keuangan syariah, maka tersedia dan terbuka berbagai peluang baik secara budaya, maupun struktural yang harus segera ditangkap. Secara struktur seperti kebijakan pemerintah pusat untuk penyaluran kredit kepada UMKM.
\end{abstract}

Kata Kunci: UMKM, Koperasi, Pengentasa Kemiskinan

\section{Pendahuluan}

Dalam Tatanan kehidupan ekonomi, koperasi, usaha kecil dan menengah mempunyai peranan penting dalam upaya mengentaskan kemiskinan. Koperasi dan UKM akan memberikan kesempatan berusaha dan kesempatan kerja sebagai perwujudan dari program pemberdayaan ekonomi masyarakat

Sasaran pemberdayaan ekonomi masyarakat dapat dilihat dari sisi sebagai berikut: Pertama, menciptakan suasana atau iklim yang memungkinkan potensi masyarakat berkembang (enabling). Kedua, memperkuat potensi atau sumberdaya yang dimiliki oleh masyarakat (empowering). Ketiga, proses pemberdayaan harus melindungi dan mencegah (protecting) yang lemah bertambah lemah disebabkan kekurangberdayaan dalam menghadapi yang kuat. 
Dalam perspektif pemberdayaan, keberadaan usaha kecil menengah dengan segala karekteristiknya dituntut untuk menangkap peluang dalam situasi ekonomi yang sangat sulit, yaitu fleksibelitas yang tinggi, dan dengan dukungan manajemen yang memadai dalam menghasilkan produk dan jasa.

Secara umum dapat dikemukakan beberapa karakteristik UMKM, antara lain: (a) Proses produksi dan hasil produksi menggunakan teknologi madya dan sederhana, (b) Menyerap tenaga kerja (padat karya) dan tidak mensyaratkan keahlian khusus, (c) Cenderung tumbuh berkelompok membentuk sentra menurut jenisnya, (d) Tumbuh dan berakar dari bakat ketrampilan yang bersifat turun temurun.

Mengacu pada karakteristik yang dimiliki, usaha kecil dan menengah (UMKM) menggambarkan adanya beberapa keterbatasan berupa lemahnya kemampuan mengakses sumber-sumber kemajuan usaha. Kendala berupa rendahnya kemampuan dan akses yang ada pada UMKM tersebut, antara lain: (a) Rendahnya kemampuan akses pada sumber-sumber informasi. (b) Rendahnya kemampuan untuk meningkatkan akses dan peluang pasar. (3) Rendahnya kemampuan dan akses terhadap sumbersumber permodalan termasuk perbankan. (4) Rendahnya kemampuan dalam penguasaan dan pemanfaatan teknologi. (5) Rendahnya kemampuan dalam mengembangkan organisasi dan manajemen. (6) Lemahnya pembentukan jaringan usaha atau kemitraan antara sesama usaha kecil dan besar.

Berdasarkan permasalahan koperasi dan UMKM, diperlukan strategi pemberdayaan usaha dalam rangka memunculkan usaha masyarakat yang produktif dan prospektif.

Untuk itu membedah permasalahan di atas, perlu dirumuskan masalah-masalah yang menjadi fokus tulisan ini, yaitu: Bagaimana kondisi koperasi dan UMKM saat ini, dan bagaimana bentuk peran dari koperasi dan UMKM yang dapat mengentaskan kemiskinan dan mengurangi pengangguran; Bagaimana peranan lembaga keuangan syariah yang ada saat ini dalam memberdayakan koperasi dan UKM; Apa saja strategi yang dapat diterapkan agar terjadi pemberdayaan Koperasi dan UMKM yang mandiri 
dan tangguh; Upaya-upaya apa yang perlu dilakukan agar pemberdayaan koperasi dan usaha mikro, kecil, dan menengah (UMKM) dapat mengambil peran yang berarti dalam menanggulangi kemiskinan dan mengurangi pengangguran.

Dari beberapa pertanyaan kunci ini penulis mencoba melakukan analisis lebih jauh guna memberi solusi yang mungkin dapat dilakukan. Membicarakan persoalan koperasi dan UMKM kita tidak terlepas dari pembahasan sistem ekonomi, karena koperasi dan UMKM merupakan salah satu pelaku ril dalam perekonomian, semenatara itu kita memahami bahwa saat ini bangsa Indonesia menerapkan sistem ekonomi campuran, ada model kapitalisme atau mekanisme pasar yang menentukan semua aspek perekonomian yaitu apa yang diproduksi, kepada siapa dan bagaimana distribusinya, disisi lain ada model sosialisme yang mana dicirikan masih adanya beberapa kebijakan ekonomi yang masih ditangan negara, semenatara itu sistem syariah masih sementara mencari bentuk.

Kondisi bangsa Indonesia saat ini masih jauh dari harapan khususnya masih terjadinya ketimpangan dari segala aspek prikehidupan baik ekonomi, antar wilayah, maupun sosial dan hukum. Untuk itu dapat disimpulkan bahwa system ekonomi yang dianut bangsa Indonsia saat ini tidak mampu menyelesaikan masalah, terbukti orang miskin tambah miskin, lapangan pekerjaan tidak tercipta secara memadai sehingga pengangguran makin bertambah, sementara yang kaya makin kaya.

Jalan keluar dari semua masalah adalah perlunya penerapan system ekonomi islam yang dianggap lebih sesuai dan diyakini mampu mewujudkan pemerataan dan keadilan yang berkelanutan sehinggga tercipta kesejahteraan masyarakat Indonesia yang berdasarkan ajaran islam yang dicitakan yaitu Masyarakat Madani.

Sistem ekonomi islam diyakini mampu membawa masyarakat islam Indonesia untuk dapat sejajar dengan bangsa lain dalam membangun perekonomian, mengapa demikian karena Indonesia merupakan negara yang mempunyai pemeluk Islam terbesar di dunia. Untuk itu diperlukan upaya mengkaji dan mengembangankan ekonomi islam lewat seminar, penelitian terapan dan penerapan atau praktek di dunia usaha prinsip- 
prinsip ekonomi islam agar dapat terwujud masyarakat yang sejahtera, adil dan makmur berdasarkan syariat Islam.

Salah satu yang diinginkan Islam adalah perekonomian yang tidak mengenal bunga karena ini dianggap riba, larangan riba sudah sejak nabi Musa dan nabi Isa. selain itu islam melarang perbuatan apa saja termasuk konteks ekonomi yang membahayakan kepentingan diri pribadi, dan kepentingan masyarakat. Riba atau memperbungakan uang merupakan perampasan terhadap kelelahan orang lain, merupakan penghisapan tenaga oleh orang yang bermodal cukup, bahkan dapat melenyapkan jiwa gotong-royong dan tolong menolong serta percaya mempercayai. Allah SWT berfirman: "Hai orang-orang yang beriman, takutlah kepada Allah dan tinggalkan apa-apa yang tertinggal dari hal riba, kalau benar-benar kamu itu beriman." (al-Baqarah:278). Lebih lanjut seperti dalam al-Quran 2:275 " dan Allah menghalalkan jual beli dan melarang riba."

Siapa yang bertanggung jawab mewujudkan masyarakat yang islami, kita sendiri sebagai warga muslim yang oleh Allah SWT ditunjuk sebagai Khalifah di bumi dengan demikian kita mendapat amanah untuk memakmurkan bumi beserta isinya dan menjaga kelestariannya (al-Baqarah: 30, al-An'am: 165, Faathir: 39, Shad: 28, dan al-Hadid: 7).

Saat ini peranan koperasi dan Usaha mikro kecil dan menengah (UMKM) sangat diharapkan guna memulihkan perekonomian agar bisa segera pulih dari krisis, mengingat koperasi dan UMKM sangat besar peranannya dalam menyerap tenaga kerja dan meningkatkan produksi dan jasa di masyarakat, namun salah satu tantangan sekaligus peluang adalah sanggupkah koperasi dan UMKM menerapkan sistim syariah sebagai dasar dari semua aspek usaha yang pada akhirnya memberi peluang bagi koperasi dan UMKM bekerja berdasar syariah Islam, secara khusus memanfaatkan keberadaan LKS.

Keberadaan UMKM perlu memaksimalkan potensi yang dimiliki, namun saat ini masih banyak penerapan aturan yang tidak kondusif bagi pengembangan UMKM misalnya terlalu banyaknya pungutan dan biaya-biaya yang diterapkan sehingga mengakibatkan biaya tinggi, belum lagi pengurusan ijin yang selain menghabiskan waktu juga sangat mahal, yang mana bagi UMKM yang baru memulai usaha merupakan 
beban yang sangat berat mengingat pemasukan belum ada sudah harus mengeluarkan biaya perijinan yang tidak sedikit. Fenomena ini merupakan suatu kontaproduktif sebab harusnya pihak pemerintah memberi kemudahan lebih dahulu baru meminta hak, atau dengan kata lain bagaimana memperbanyak obyek yang akan dipungut supaya lebih banyak, jangan seperti saat ini menambah pungutan yang sudah ada. Sesuai data tahun 2003 jumlah tenaga kerja yang ditampung oleh usaha mikro dan kecil 7,4 juta orang, usaha menengah 1,2 juta orang, usaha besar 55.760 orang, sementara itu kepedulian pemerintah daerah terhadap UMKM masih relatif rendah hal terlihat dari alokasi anggaran untuk pengembangan UMKM baru 0,85 \% secara rata-rata dari Anggaran Pendapatan dan belanja daerah. Jika kita melihat data ini maka kita dapat mengatakan bahwa solusi terbaik untuk mengurangi pengangguran adalah pemberdayaan UMKM melalui LKS.

Untuk itu apa yang diperlu dilakukan, bagaimana melakukannya, dan yang mana harus diprioritaskan dalam rangka pengembangan koperasi dan UMKM yang berwawasan mandiri dan tangguh melaui LKS. Yang pertama sekali harus dilakukan adalah meyakini bahwa koperasi dan UMKM merupaan pelaku ekonomi yang memiliki peran yang besar dalam mensejahterakan masyarakat melalui aktivitas sosial dan ekonomi yang dilakukan, Sebagai contoh konkrit negara maju yang berhasil dengan UMKM misalnya Amerika Serikat, Canada, Perancis, Jerman, (Eropah Umumnya) Jepang, Korea Selatan, dan Singapura. Salah satu hal yang diperlukan adalah kebijakankebijakan penyesuaian dari kebijakan sentralistis ke kebijakan yang berbasis daerah setempat, dimana UMKM dan LKS sebagai salah satu pelaku ekonomi yang bertujuan mensejahterahkan masyarakat keberadaannya betul-betul bermanfaat bagi masyarakat setempat atau daerah sehingga daerah dapat menikmati hasil dari keberadaan UMKM tersebut.

Selain itu guna mencermati perkembangan keadaan maka koperasi dan usaha mikro kecil menengah harus menyesuaikan diri dengan perkembangan keadaan khususnya penerapan model syariah dalam perekonomian salah satunya adalah pengembangan LKS. yang akan memiliki tantangan dan peluang yang jika tidak dipersiapkan dengan baik bisa jadi akan menghambat pengembangan koperasi dan UMKM. 


\section{Kondisi umum Koperasi}

Koperasi sebagai salah satu pelaku ekonomi yang diharapkan menjadi soko guru perekonomian nasional hingga saat ini masih jauh dari yang diharapkan, hal ini salah satu penyebabnya adalah undang-undang yang digunakan tidak memiliki kapasitas untuk membangun koperasi yang sehat dan mandiri, selain itu kebijakan pelatihan perkoperasian yang mengandalkan bantuan pemerintah, melahirkan ketergatungan, sehingga daya kreatifitas menjadi tumpul untuk membangun diri sendiri lewat kemampuan sendiri.

Selain itu masih terdapat beberapa faktor kelemahan yang menjadi penghambat kemajuan koperasi antara lain: Pertama, citra koperasi. Sejauh ini citra koperasi di masyarakat secara umum belum baik. Buktibukti empiris menunjukkan perkembangan koperasi secara umum masih belum memenuhi harapan, apalagi untuk mewujudkan koperasi yang genuine. Selama ini koperasi masih dipandang sebagai badan usaha yang memiliki kinerja kurang baik atau lemah dan dianggap sebagai wadah golongan ekonomi lemah dan kurang potensial untuk diajak bekerjasama oleh badan usaha lainnya.

Kedua, kemandirian koperasi. Pola pembinaan yang diterapkan selama ini telah menimbulkan ketergantungan koperasi pada program pemerintah. Dalam menentukan kepengurusan koperasi seringkali terjadi intervensi pemerintah yang mengakibatkan koperasi tidak cukup memiliki otonomi dan kemandirian dalam pengambilan keputusan, khususnya melalui rapat anggota sebagai kekuasaan tertinggi dalam struktur koperasi. Kenyataan ini menujukkan bahwa pelaksanaan nilai dan prinsip dasar yang hakiki koperasi masih belum terwujud.

Ketiga, sumber daya manusia. Keterbatasan pengetahuan dan pemahaman para pengelola koperasi tentang teknis perekonomian, terutama hakikat dan ciri-ciri koperasi sebagai badan usaha. Di samping itu , orang- orang yang diserahi tugas untuk mengelola koperasi masih belum memiliki wawasan, pengetahuan, dan ketrampilan kewirausahaan yang memadai, sehingga berdampak terhadap perkembangan dan kinerja koperasi, kurang memadainya pelaksanaan prinsip- prinsip koperasi, serta rendahnya partisipasi anggota. 
Keempat, manajemen. Kualitas sumberdaya manusia (SDM) koperasi yang terbatas telah berdampak pada manajemen koperasi yang belum profesional. Keseluruhan fungsi manajemen belum dilaksanakan secara profesional, sehingga koperasi belum menunjukkan perkembangan dan kinerja yang memadai.

Kelima, permodalan. Kemampuan pemupukan permodalan koperasi relatif masih sangat terbatas sebagai akibat partisipasi anggota dalam pemupukan modal koperasi yang sangat rendah. Hal ini disebabkan kesadaran dan kemampuan ekonomi anggota yang masih rendah. Di lain pihak, akses koperasi pada sumber- sumber permodalan/ pembiayaan juga masih sangat terbatas, akibat belum berkembangnya usaha koperasi yang memiliki kenyataan ekonomi dan rendahnya kredibilitas koperasi dihadapan para kreditur.

Keenam, cakupan dan Skala Usaha. Cakupan dan skala usaha koperasi pada umumnya masih sangat terbatas dan cenderung terkait dengan program pemerintah terutama di sektor pertanian seperti dalam program produksi dan pengadaan pangan. Kegiatan yang bersifat non program biasanya dalam bentuk penjualan eceran ( waserda, toko, warung ) dan usaha simpan- pinjam, yang volume usahanya masih relatif kecil.

Ketujuh, kerjasama usaha. Kerjasama usaha antar koperasi, baik secara vertikal maupun horisontal dan dengan badan usaha lainnya, masih belum berkembang dengan memadai. Peran koperasi sekunder yang diharapkan dapat mendukung kegiatan usaha koperasi primer kurang optimal.

Dalam sejarah dan pengembangan koperasi di Indonesia, prakarsa pengenalan dan pendirian koperasi pada umumnya dimotori oleh aparat pemerintah, yang kemudian berkembang sejalan dengan tumbuhnya partisipasi masyarakat. Dalam hal pengendalian pembinaannya, sejak awal perkembangannya telah dilakukan oleh pemerintah secara berkesinambungan. Perkembangan koperasi di Indonesia telah melalui beberapa periode, yaitu mulai dari jaman penjajahan, masa awal kemerdekaan, masa Orde Lama, masa Orde Baru, dan era reformasi.

Paradigma yang lebih mengutamakan pada pertumbuhan kuantitas 
pada masa lalu telah mendorong tumbuhnya koperasi yang diprakarsai pemerintah ( top down approach ) daripada yang tumbuh atas prakasa sendiri ( bottom- up appoach ). Keadaan semacam ini membuat koperasi tidak memiliki fundamental yang kokoh ( solid) dalam pertumbuhannya, karena besarnya intervensi pemerintah dalam pembinaan koperasi, sehingga banyak koperasi yang telah berbadan hukum tapi tidak aktif melaksanakan aktivitas.

Dari beberapa uraian diatas menunjukkan bahwa Koperasi masih memiliki kelemahan yang cukup mendasar, untuk itu diperlukan konsepkonsep srategis yang mendasar dan komprehensif guna memecahkan beberapa masalah yang dihadapi agar koperasi dapat berperan sebagai agen pembaharu dan penggerak utama ekonomi nasional,

\section{Karakteristik, Problema, dan Defenisi UMKM}

Untuk melakukan pemberdayaan yang komprehensif maka kita perlu memahami karakteristik dan problema UMKM, sehingga dengan mengetahui kondisinya maka dapat dilakukan diagnosa lebih baik untuk menentukan solusi terbaik. Adapun karakteristik UMKM adalah sebagai berikut: (1) Mempunyai skala usaha yang kecil baik modal, penggunaan tenaga kerja maupun orientasi pasar. (2) Banyak berlokasi di pedesaan, kota-kota kecil atau daerah pinggiran kota besar. (3) Status usaha milik pribadi atau keluarga. (4) Sumber tenaga kerja berasal dari lingkungan sosial budaya (etnis, geografis) yang direkrut melalui pola pemagangan atau melalui pihak ketiga. (5) Pola kerja seringkali part time atau sebagai usaha sampingan dari kegiatan lainnya. (6) Memiliki kemampuan terbatas dalam mengadopsi teknologi, pengelolaan usaha dan administrasinya sederhana. (7) Struktur permodalan sangat terbatas dan kekurangan modal kerja serta sangat tergantung terhadap sumber modal sendiri dan lingkungan pribadi. (8) Izin usaha seringkali tidak dimiliki dan persyaratan usaha tidak dipenuhi. (9) Strategi perusahaan sangat dipengaruhi oleh kondisi lingkungan yang sering berubah secara cepat.

Setelah memahami karakteristik UMKM maka langkah lebih lanjut adalah memahami permasalahan-permasalahan yang ada di dunia UMKM, 
adapun permasalahan tersebut antara lain: (1) Kelemahan dibidang organisasi dan manajemen. (2) Kelemahan dalam struktur permodalan dan keterbatasan untuk memperoleh jalur akses terhadap sumber-sumber permodalan. (3) Kelemahan dan memperoleh peluang (akses pasar) dan memperbesar pangsa pasar. (4) Keterbatasan dalam kelemahan pemanfaatan akses dan penguasaan teknologi, khususnya teknologi terapan. (5) Masih rendahnya kualitas SDM yang meliputi aspek kompetensi, keterampilan, etos kerja, karakter, kesadaran akan pentingnya konsisten mutu dan standarisasi produk dan jasa, serta wawasan kewirausahaan. (6) Keterbatasan penyediaan bahan baku mulai dari jumlah yang dapat dibeli, standarisasi kualitas yang ada, maupun panjangnya rantai distribusi bahan baku. (7) Sistem kemitraan yang pernah digulirkan selama ini, cenderung mengalami distorsi di tingkat implementasi sehingga berdampak pada sub-ordinasinya pelaku usaha mikro, kecil, dan menengah dibandingkan dengan mitra usahanya (usaha besar).

\section{Defenisi UMKM}

Agar lebih lengkap pemahaman kita terhadap UMKM maka ada baiknya melihat beberapa defenisi yang ada dari berbagai pihak yang memiliki keterkaitan dengan UMKM, defenisi tersebut sebagai berikut:

\section{Berbagai versi definisi dan kriteria}

\section{Usaha kecil dan menengah}

\begin{tabular}{lll}
\hline Organisasi & Jenis usaha & Keterangan kriteria \\
\hline Undang-Undang No & Usaha Kecil & Aset < Rp 200 juta di luar tanah \\
9/1995 tentang Usaha & & dan bangunan. Omzet tahunan \\
Kecil & & Rp 1 milyar. Dimiliki oleh \\
& & orang Indonesia. Independen, \\
& & tidak terafiliasi dengan usaha \\
& & menengah -besar. Boleh berbadan \\
& & hukum, boleh tidak. \\
\hline Badan Pusat Statistik & Usaha Mikro & Pekerja 5 orang, termasuk tenaga \\
(BPS) & & keluarga yang tidak dibayar \\
\hline
\end{tabular}




\begin{tabular}{|c|c|c|}
\hline & Usaha Kecil & Pekerja $<5-19$ orang \\
\hline & Usaha Menengah & Pekerja 10-99 pekerja \\
\hline \multirow{5}{*}{$\begin{array}{l}\text { Menneg Koperasi \& } \\
\text { PKM }\end{array}$} & Usaha Kecil (UU & Aset $<$ Rp 200 juta di luar tanah \\
\hline & No.9/1995) & dan bangunan. Omzet $<$ Rp 1 \\
\hline & & milyar \\
\hline & Usaha Menengah & Aset Rp 200 juta - Rp 10 milyar \\
\hline & (Inpres 10/1999) & \\
\hline \multirow[t]{14}{*}{ Bank Indonesia } & Usaha Mikro (SK & Usaha yang dijalankan oleh rakyat \\
\hline & Dir BI No. 31/24/ & miskin atau mendekati miskin. \\
\hline & KEP/DIR tgl 5 Mei & Dimiliki keluarga. Sumberdaya \\
\hline & 1998) & lokal dan teknologi sederhana. \\
\hline & & Lapangan usaha mudah untuk exit \\
\hline & & dan entry. \\
\hline & Usaha Kecil (UU & Aset $<$ Rp 200 juta di luar tanah \\
\hline & No. 5/1995) & dan bangunan. \\
\hline & & Omzet tahunan $<$ Rp 1 milyar \\
\hline & Usaha Menengah & Aset $<\operatorname{Rp} 5$ milyar untuk sektor \\
\hline & (SK Dir BI No. & industri. Aset < Rp 600 juta di luar \\
\hline & 30/45/Dir/UK tgl 5 & tanah dan bangunan untuk sektor \\
\hline & Januari 1997) & non-industri manufacturing. \\
\hline & & Omzet tahunan $<$ Rp 3 milyar \\
\hline \multirow[t]{4}{*}{ Bank Dunia } & Usaha Mikro & Pekerja $<20$ orang \\
\hline & Kecil-Menengah & Pekerja $20-150$ orang \\
\hline & & Aset $<$ US\$ 500 ribu di luar tanah \\
\hline & & dan bangunan. \\
\hline
\end{tabular}

Salah satu persoalan yang perlu mendapat perhatian adalah terlalu banyaknya defenisi UMKM dari berbagai versi, yang mana menyulitkan dalam pemeringkatan khususnya terkait program pembinaan.

\section{Kemiskinan dan Pengangguran}

Acuan kita selama ini tentang penyebab kemiskinan biasanya melihat dari dua sebab yaitu kemiskinan yang berifat struktural dan kemiskinan 
yang kultural. Kemiskinan struktural antara lain diakibatkan pengelolaan sumberdaya yang dimiliki tidak merata, akses dan kemampuan masyarakat yang tidak seimbang, dan adanya ketidakadilan dalam memperoleh kesempatan kerja dan usaha, yang pada akhirnya menyebabkan terjadinya kesenjangan pendapatan, yang lebih lanjut menimbulkan kesenjangan dalam struktur masyarakat. Secara umum biasanya dikatakan bahwa kemiskinan struktural ini lebih diakibatkan dari pengelolaan tatanan sosial ekonomi dan politik yang tidak bersifat adil.

Salah satu tujuan utama dari konsep ekonomi islam adalah bagaimana mewujudkan keadilan disegala bidang agar terjadi pemerataan kesempatan usaha dan kesempatan kerja. Al-Quran menempatkan keadilan sebagai salah tujuan utama yang akan dicapai oleh para rasul Allah SWT (al-Hadid: 25), dan keadilan merupakan derajat yang mendekati taqwa (al-Maidah: 8). Hadis Nabi Muhammad mengatakan "orang yang paling dicintai dan paling dekat kedudukannya di sisi Allah pada hari kiamat adalah seorang penguasa yang adil, sebaliknya orang yang paling dibenci dan jauh kedudukannya disisi Allah adalah penguasa tidak adil"

Kemiskinan kultural biasanya dihubungkan dengan sikap dan prilaku seseorang atau kelompok masyarakat yang banyak dipengaruhi oleh kebiasaan, atau gaya hidup serta sikap budaya yang menurut mereka kehidupannya tidak bisa lagi diperbaiki dan cenderung pasrah dan tidak berupaya untuk keluar dari keadaan tersebut, misalnya bagaiman memperbaiki tingkat pendapatan yang menurut ukuran umum dianggap miskin, tetapi bagi mereka tidak merasa miskin dan juga tidak mau disebut miskin.

Sehubungan dengan uraian diatas, maka Allah SWT melarang kefakiran, yang olh Allah SWT digambarkan sebagai seorang yang mengikat tangannya sendiri dan dibelenggunya dilehernya, seperti yang tercantum dalam al-Quran surat al-Isra: 29, "Jangan engkau menjadikan tanganmu terbelenggu dilehermu (kikir) dan jangan pula membeberkannya melebihi batas (terlampau dermawan), sebab akhirnya engkau akan menjadi hina dan miskin."

Secara ril atau keseharian kemiskinan kita bisa lihat dari berbagai segi: antara lain miskin harta, miskin ilmu, miskin kesehatan, dan miskin nilai- 
nilai moral. Kata lainnya miskin sandang, pangan, perumahan, kesehatan, pendidikan dan ahlak mulia. Namun akar dari semuanya adalah miskin harta dan miskin ahlak mulia. Indikator kemiskinan juga cukup beragam ada versi Dep. Sosial, Versi Depdiknas, ada versi BKKBN. Dan ada versi masyarakat.

Pengalaman penulis dari berbagai program penanggulangan kemiskinan dimana penulis pernah terlibat langsung, mulai dari program Local Economic Development Unit (LEDU) dari ILO, Program pengembangan kecamatan (PPK) dari Bank Dunia, Community based development (CBD) juga dari bank Dunia, Pengurangan kemiskinan nelayan dari Canada Fund, dan terakhir dari Urban Poverty Project (proyek penanggulangan kemiskinan perkotaan-P2KP) dari bank dunia. Intisari dari semuanya mengacu pada bagaimana menumbuh kembangkan penerapan ahlak mulia atau nilai-nilai luhur dalam pengembangan organisasi masyarakat. Karena dengan organisasi masyarakat yang baik maka organisasi sosial, ekonomi, juga akan baik, maka diharapkan dengan baik lembagalembaga yang ada di masyarakat dapat dengan segera membantu keluar dari berbagai permasalahan kemiskinan.

Hadis Rasullullah SAW. mengatakan: "Bekerjalah untuk duniamu seakan-akan kamu akan hidup selamanya dan beribadahlah untuk akhiratmu seakan-akan kamu akan mati besok". Hadis ini harusnya dapat menjadi motivator utama bagi masyarakat muslim agar dapat mengubah nasib dan dapat keluar dari kemiskinan.

Al-Quran menempatkan orang yang bekerja sebagai keutamaan seperti dalam firmanNya: (al-Jumu'ah: 10) selain itu kita diwajibkan memberi kepada kaum miskin dari harta yang diamanahkan Allah SWT11 kepada kita seperti firmanNya (an-Nur:33): "berilah mereka (kaum fakir miskin) itu dari harta allah yang telah dikaruniakan padamu." Beberapa acuan yang telah disebutkan hendaknya dapat menjadi landasan kita kaum muslim untuk bekerja bersama dan saling tolong berdasarkan syariah untuk berjuang bersama memerangi kemiskinan.

Indonesia saat ini mempunyai masyarakat miskin sekitar 36,7 juta jiwa, suatu jumlah yang sangat besar, ukuran kemiskinan yang digunakan adalah Indikator ekonomi dengan pendekatan garis kemiskinan berupa jumlah 
pengeluaran perkapita untuk tahun 2002 sekitar Rp 114.000,-perkapita perbulan. Jadi siapa saja yang pengeluarannya dibawah garis tersebut masuk kategori miskin. Untuk tahun 2005 sekitar Rp135.000,- perkapita perbulan. Secara terinci ukuran ini dipilah lagi antara perdesaan dan perkotaan.

Banyak program yang telah dilakukan namun kenyataannya belum memberi hasil yang memadai, semua sektor mengagendakan program penanggulangan kemiskinan, khususnya program yang berkaitan kebutuhan dasar masyarakat yaitu sandang, pangan, perumahan, kesehatan dan pendidikan. Banyak orang mengatakan bahwa di era orde baru justru program penanggulangan kemiskinan lebih jelas arahnya misalnya saja adanya delapan jalur pemerataan, saat ini banyak program namun yang terjadi tidak tepat arah dan tidak tepat sasaran. Kita perlu rancang bangun yang baru agar kita dapat memastikan bahwa program tersebut tepat arah dan tepat sasaran.

Banyak ahli mengemukakan bahwa salah satu cara mengurangi kemiskinan adalah mengurangi penduduk, dan meningkatkan daya dukung sumberdaya alam, saat ini penduduk dunia berjumlah 6,5 milyar orang, Indonesia sekitar 210 juta Jiwa, dan menurut Perserikatan bangsabangsa 45 tahun yang akan datang tepatnya tahun 2050 penduduk dunia berjumlah 9,1 milyar. Jumlah penduduk 6,1 milyar saat ini merupakan akumulasi pertambahan yang panjang sejak ribuan tahun yang lalu, dan jika kita bandingkan pertambahan 45 tahun yang akan datang yang diproyeksikan sebesar 2,6 milyar adalah suatu jumlah spektakuler, siapa atau negara mana yang memberi kontribusi terbanyak, rupanya negaranegara asia khususnya India dan China. Negara maju cenderung statis, karena program satu keluarga satu anak sudah berhasil. Indonesia program satu keluarga dua anak sedikit berhasil. Dapat kita bayangkan bagaimana memberi kebutuhan dasar bagi penduduk sebesar itu. Untuk itu cara terbaik adalah bagaimana meningkatkan sumberdaya manusia, dan bagaimana meningkatkan daya dukung sumberdaya alam. Dari segi sumberdaya alam Indonesia cukup memadai, yang belum adalah sumberdaya manusia khususnya ilmu pengetahuan, teknologi, ahlak mulia. 
Penerapan Syariah islam dalam segenap aspek kehidupan diyakini sebagai jalan keluar terbaik dari bangsa Indonesia, mengapa demikian, karena Syariah sangat komitmen dan relevan pada penggalian dan pewarisan ahlak mulia dan nilai-nilai luhur. Kejujuran, keadilan, kesederhaan, kedermawanan, dan kesetiakawanan, keihlasan, dan ketidak serakahan yang mana kesemuanya merupakan nilai-nilai yang akan diperjuangkan oleh syariat islam.

\section{Lembaga Keuangan Syariah: Solusi terbaik}

Sistem ekonomi Islam khususnya, Lembaga keuangan Syariah dan segenap perangkat lembaga yang dimiliki mulai yang berbentuk Bank Syariah, Koperasi Syariah, sampai BMT, serta para pengelolanya mulai dari Karyawan, manajer, dan Direksi dan staf pendukung serta pengawas hingga saat ini belum memiliki perangkat hukum formal yang dianggap memadai didalam operasional sehingga berhak mengelola sumberdaya negara yang dimiliki. Saat ini LKS banyak dilirik sebagai jawaban atas masalah kemiskian dan pengangguran sebaba seperti telah terbumti dibeberapa negara Islam misalnya Banglades dengan Grameen banknya yang terkenal.

Lawan kemiskinan adalah kesejahteraan, dan biasanya jika sudah sejahtera, ukuran kemiskinan yang lain sudah dianggap teratasi yaitu kecerdasan, kesehatan juga sandang dan pangan. Secara singkat dapat dikemukakan bahwa jika ingin meningkatkan kesejahteraan menurut syariah Islam maka ada dua aspek pokok yang harus diperbaiki yaitu pendapatan dan pendidikan, atau dengan kata lain bagaimana meningkatkan dan mendistribusikan pendapatan berdasarkan syariah serta bagaimana agar sebanyak mungkin orang menikmati pendidikan yang sesuai syariah. Hal ini dapat dijelaskan lebih jauh bahwa jika pendapatan meningkat maka tabungan meningkat jika tabungan meningkat maka modal kerja dan modal investasi tersedia, jika kedua modal yang menggerakkan dunia usaha ini tersedia maka akan meningkatkan kesempatan usaha dan kesempatan kerja dan jika ini terjadi produktivitas meningkat, yang pada akhirnya pengangguran dapat dikurangi dan muaranya kesejahteraan akan meningkat. Firman Allah SWT 
al-A'raaf:96 “Jikalau sekiranya penduduk negeri-negeri itu beriman dan bertaqwa, pastilah Kami akan melimpahkan kepada mereka berkah dari langit dan bumi"

Sisi yang lain yang perlu mendapat perhatian adalah pendidikan yang sesuai syariah, jika pendidikan meningkat maka jumlah tenaga ahli meningkat, jumlah tenaga terampil meningkat, dan jumlah wirausaha meningkat, peningkatan dari kesemua variabel pada akhirnya akan meningkatkan produktifitas yang muaranya akan meningkatkan kesejahteraan.

Penerapan Syariat islam khususnya dalam bidang ekonomi mengharapkan semua masyarakat islam mampu mengeksplorasi daya dukung sumberdaya alam yang kita miliki, dan mengelolanya yang disertai sikap moralyang mengutamakan ahlak mulia dan solidaritas bersama yang sangat diharapkan menghilangkan KKN. Syariat Islam mengawali semuanya dari ahlak mulia, kemudian pendidikan secara bersama, pendapatan akan dikreasiakan lewat Bantuan permodalan dari lembaga keuangan syariah dengan perkuatan organisasi yang sesuai syariah yang pada akhirnya ke lembaga keuangan mikro (LKM). Tapi yang paling penting bagi syariat islam adalah ahlak mulia dan penerapan nilai-nilai luhur, dalam wadah organisasi yang baik sesuai Islam.

Lembaga Keuangan Syariah merupakan peletak dasar, pendorong dan penggerak penanggulangan kemiskinan secara berkelanjutan atas dasar kekuatan dan kemampuan sendiri. inilah yang perlu ditebarkan kesemua strata masyarakat Islam di Indonesia. Jika mata air bersih maka air yang mengalir pasti bersih, jika mata air kotor maka air yang mengalir juga kotor. Orang yang berbuat baik memang rejeki belum tiba tapi bencana sudah tiada. Orang yang berbuat jahat memang bencana belum tiba tapi rejeki sudah menjauh. Untuk itu mari sempurnakan niat dan sempurnakan upaya lewat penerapan lembaga keuangan syariah. Rasulullah Muhammad SAW mengatakan "jika hari ini anda lebih jelek dari hari kemarin itu berarti anda rugi, seharusnya hari ini lebih baik dari hari kemarin", baik dalam niat, bertindak, berpikir, bekerja, beribadah dan bermuamalah. 


\section{Fokus LKS: Kredit Mikro}

Pemerintah Republik Indonesia mencanangkan tahun 2005 sebagai tahun keuangan mikro, hal ini sejalan dengan keinginan badan dunia perserikatan bangsa-bangsa (PBB) yang juga menetapkan tahun kredit mikro, hal mana telah lama diperjuangkan sejak tahun 1997 sudah menjadi agenda badan dunia tersebut, karena diharapkan dengan berjalannya secara baik program kredit mikro maka permasalahan utama dunia yaitu kemiskinan dapat dikurangi atau ditanggulangi.

Apa sebenarnya kredit mikro tersebut secara umum pengertiannya adalah kredit yang dikucurkan kesektor usaha mikro dengan batasan 50 juta rupiah kebawah, dan saat ini implementasi dilapangan adalah kredit yang dibawah 5 juta rupiah dan tanpa agunan, atau dikenal juga sebagai kredit tanpa agunan (kredit kepercayaan). Kenapa kredit kepercayaan karena diharapkan pihak perbankan menghilangkan salah satu sebab mengapa usaha mikro sulit mengakses lembaga perbankan atau lembaga pembiayaan adalah karena diperlukan agunan, dan inilah yang menjadi masalah utama usaha mikro karena perbankan biasanya mensyaratkan adanya jaminan berupa sertifikat rumah, sertifikat deposito, atau jaminan lain misalnya buku pemilik kendaraan bermotor (BPKB), yang kesemua ini bagi usaha mikro sangat sulit karena jangankan sertifikt rumah, rumah aja masih numpang dikeluarga atau masih kontrak. Apalagi sertifikat deposito sudah jauh, karena tabungan aja tidak ada. Yang ada bagi mereka adalah keinginan berusaha atau usahanya yang ada perlu mendapat sentuhan dana sebagai modal awal untuk bergerak.

Mereka memiliki potensi untuk menggerakkan roda perekonomian, mengapa tidak diberi perlakuan tersendiri dengan misalnya mempersiapkan terlebih dahulu, dengan memberi visi bisnis dan nilai-nilai islami agar mereka bisa berkembang dan usahanya bisa maju, kemudian memberi kesempatan berkelompok 3 sampai 5 orang, dan pemberian kredit diurut sesuai tingkat keperluan mereka dan biarkan mereka sendiri yang tentukan jadwalnya atau bisa sekaligus diberi kredit tapi dengan model tanggung renteng yaitu jika ada anggota kelompok yang tidak bayar maka yang lain ikut menanggung.

Marikita melihat perkembanganyang terjadi ahir-akhiriniyang sungguh 
sangat mengusik rasa keadilan mendengar dan melihat pemberitaan kredit macet yang ada di bank mandiri dan bank yang lain, kredit macet bisa dikatakan sebagai kredit tanpa angsuran, karena ada beberapa pengusaha besar yang setelah menerima kredit maka selanjutnya tidak pernah mengangsur sekalipun, apa sebenarnya yang terjadi, kita melihat aparat yang berkompeten masih melalukan pengkajian saksama tentang keberadaan kredit macet itu apakah macet atau sengaja di macetkan, sudahlah kasus ini merupakan permasalahan yang sudah sering terjadi dinegara kita dan masyarakat sudah menganggap keadaan ini dengan sikap acuh dan tak berdaya melihat betapa ketimpangan dan kesenjangan yang terjadi akibat adanya perbedaan perlakuan dalam pembagian asset yang serba tidak jelas aturan mainnya, kita merasa sungguh sangat tidak adil jika kita bandingkan upaya yang kita perjuangkan bagaimana agar kredit kepercayaan berupa kredit mikro tanpa agunan yang jumlahnya antara Rp 500.000 sampai Rp 5.000.000,- dengan persyaratan usaha sudah ada dan KTP atau surat rekomendasi desa/lurah dapat terealisasi agar masyarakat kecil pelaku usaha gurem juga dapat menikmati asset bangsa ini belum juga terwujud.

Contoh kasus kredit macet bank Mandiri 1,3 triliun sama dengan 1300 milyar hanya dinikmati oleh segelintir orang, Cuma 5 perusahaan antara lain yaitu PT.CGN, PT.SZP., PT. LMK, PT. ABT dan PT. AT. Coba kita bayangkan seandainya kita asumsikan 1,3 T tersebut kita bagikan sebagai kredit mikro dengan jumlah setiap orang pengusaha gurem Rp $5 \mathrm{jt}$, maka akan dinikmati oleh 260.000 orang/unit usaha dan jika kita asumsikan setiap orang memiliki 3 anggota keluarga (1 isteri dan 1 anak) maka akan dirasakan oleh 780.000 orang jumlah ini setara dengan jumlah penduduk 3 kabupaten di Sul-Sel.

Berapa tenaga kerja yang dapat diserap oleh penikmat kredit macet tersebut? ya hanya segelintir orang. Kita meragukan alasan bahwa membantu usaha besar itu karena sebagai pemicu pertumbuhan, jika begini jadinya dia menjadi penghambat pertumbuhan, sudah waktunya dimensi pemerataan dijadikan sebagai misi utama dari pengelolaan asset negara yang merupakan hak kita semua.

Mengapa kredit macet terjadi, banyak sebab, mungkin terjadi analisis 
fiktif, atau mungkin melanggar Apa yang biasanya dijadikan sebagai alat evaluasi perbankan yaitu $5 \mathrm{C}+1 \mathrm{~S}$ (character, capacity, condition, capital, dan colateral serta safety) apakah sudah difungsikan dengan baik, dan jika itu kita analogkan untuk kredit mikro versi Syariah maka $5 \mathrm{~K}+1 \mathrm{~S}$ kita bisa membuat suatu indikator yang sesuai yaitu kepercayaan, kejujuran, kelayakan, keterbukaan, keadilan dan solidaritas. Atau dengan kata lain kita perlu menggali kembali dan menumbuhkan nilai-nilai luhur dan ahlak mulia yang dijunjung tinggi oleh Islam, sehingga setiap orang yang meminjam maupun pemberi pinjaman memegang teguh prinsip $5 \mathrm{~K}+1$ $\mathrm{S}$ versi yang Syariah Islam, mengapa kita tidak mau mencoba memberi kepercayaan sehingga kita akan menerima kepercayaan, pengusaha gurem tersebut dipersiapkan dengan baik, didampingi dengan baik , dan dididik untuk menatabukukan usahanya dengan baik.

Selama ini selalu didengungkan betapa besarnya jumlah kredit yang akan digulirkan untuk sektor UMKM tapi realisasinya sangat sedikit, sekedar gambaran bahwa untuk tahun 2005 diproyeksikan kurang lebih 60,4 triliun untuk sektor UMKM. Akan tetapi kita sekarang sudah berada dipertengahan tahun 2005, berapa yang sudah tersalur, yang jelas di Sul-Sel triwulan I thn ini baru untuk usaha mikro kecil dan menengah (UMKM) baru 6,99 triliun atau 53,08 persen dari total kredit yang tersalur 14,38 triliun (Kantor bank Indonesia makassar) berapa yang kesektor usaha mikro kita belum tahu persis, belum kita bicara arah dari sektor yang penyaluran sebagian besar kesektor konsumtif belum banyak yang mengarah ke sektor produktif, kepada pihak yang diberi kepercayaan untuk mengelola asset bangsa agar dapat berlaku adil dan arif yang pada akhirnya membuat kebijakan serta menerapkan kebijakan tersebut yang pro ke rakyat kecil..

\section{Penyaluran Kredit LKS}

Jika kita melihat proses penyaluran kredit lewat LKS maka kita dapat membagi dua bentuk salurannya yang pertama lewat institusi perbankan dengan mengacu pada UU perbankan No. $7 / 92$ jo. UU No. 10/1998 maka beberapa bentuk perbankan yang menyalurkan yaitu bank Perkreditan rakyat(BPR) atau BPRS (Syariah), BRI Unit, atau Badan kredit desa (BKD) 
yang perizinan dan pengawasannya lewat Bank Indonesia.

Penyaluran lewat institusi non bank kita bisa bagi dua (Formal) yaitu lewat Koperasi simpan pinjam (KSP) pengaturannya lewat undangundang koperasi No. 25 tahun 1992 yang perizinan dan pengawasannya lewat Kementerian negara koperasi dan UKM; Lembaga dana dan Kredit Pedesaan (LDKP) yang pengaturannya lewat peraturan daerah, perizinan lewat Gubrnur dan pengawasannya lewat Pemerintah Daerah. Lewat non formal yaitu LSM, KSM, BMT, UEDSP, UPPKS.

Jadi sudah waktunya lembaga keuangan syariah perbankan maupun non bank melakukan pendekatan dengan menjemput bola dengan mendekati pelaku usaha UMKM, dengan memperlakukan mereka sebagai mitra untuk sukses bersama. Kini saatnya memberikan modal kerja untuk mengembangkan usahanya, meski tetap selektif dan hati-hati. Dengan cara ini pergulatan usaha mikro, kecil dan menengah dalam mengembangkan usaha terutama yang kesulitan mendapatkan modal kerja modal investasi akan teratasi. Jadi UMKM dan lembaga keuangan syariah sama-sama berkembang.

\section{Penutup}

Berdasarkan uraian diatas maka dapat ditarik beberapa kesimpulan sebagai berikut: Pertama, upaya pengembangan koperasi dan UMKM melalaui LKS memerlukan langkah-langkah taktis dan strategis berupa peningkatan visi dan misi bisnis yang sesuai syariah Islam, sehingga tercipta SDM yang islami dan berkualitas.

Kedua, guna pengintegrasian pengembangan Koperasi dan UMKM dengan lembaga keuangan syariah, maka tersedia dan terbuka berbagai peluang baik secara budaya, maupun struktural yang harus segera ditangkap. Secara struktur seperti kebijakan pemerintah pusat untuk penyaluran kredit kepada UMKM.

Ketiga, faktor-faktor penghambat bagi koperasi dan UMKM secara eksternal dalam upaya penguatan bisnisnya antara lain: (a) Kelembagaan dan organisasi belum berfungsi baik akibat belum adanya persamaan visi, misi dan strategi dari Pemerintah untuk membangun UMKM yang secara 
berkelanjutan dan terintegrasi dengan pembangunan LKS. (b) Belum adanya kerjasama antar LKS dan jaringan antar pelaku bisnis sejenis dengan pelaku usaha LKS. (c) Belum terciptanya suatu sistem informasi dan data serta potensi usaha dari UMKM yang dapat disinergikan dengan LKS.

Keempat, faktor-faktor penghambat koperasi dan UMKM secara internal dalam pengembangan bisnisnya antara lain: (a) Kelemahankelemahan yang dianggap cukup signifikan adalah umumnya UKM latah atau hanya mengikuti industri atau usaha yang sudah maju tidak banyak yang mau merintis usaha sampai maju atau membikin usaha yang komplemen dengan usaha yang ada. (b) Umumnya UMKM tidak mengiklankan produknya. (c) Umumnya UMKM tidak memiliki strategi harga yang baik.

Kelima, sebagian besar UMKM tidak pernah mengikuti pameran produk atau pameran produk ekspsor.

\section{Pustaka Acuan}

Adnan Ath-Tharsyah. 2004. Anda dan Harta. Pustaka Al-Kautsar, Jakarta.

Chapra Umer. 2000. Islam dan Pembangunan Ekonomi. Gema Insani Press, Jakarta.

Soewardi. H. 1995. Filsafat Koperasi atau Cooperativism. UPT Penerbit IKOPIN, Bandung.

Syaid Sabid. 1981. Unsur-Unsur Kekuatan Dalam Islam. Toko Kitab Ahmad Nabhan, Surabaya.

Tasmara Toto.2002. Membudayakan Etos Kerja Islami. Gema Insani, Jakarta.

Abdul Azizi Dahlan (ed).1989. Ensiklopedi Hukum Islam. Jilid ke-1. Jakarta: Ichtiar Baru vann Hoeve.

Abdurrachman Qadir. 1998. Zakat dalam Dimensi Mahdah dan Sosial. Jakarta: Raja Grafindo Persada.

Abdurrahman al Jaziry. t. th. al Fiqh cala Mazahibil Arba ${ }^{c} a h$. Jilid ke-1. Beirut: Darul Fikri. 
Afzalurrahman. 1995. Dokrin Ekonomi Islam. Jakarta: Logos.

Anis, Ibrahim. Al-Mu cjam al-Wasid.

Faris, Muhammad Abdul Kadir Abu. t. th. Kajian Kritis Pendayagunaan Zakat. Semarang: Dina Utama

Habsyi, Muhammad Baqir. 1989. Fiqih Praktis Menurut al-Qur'an, Sunnah dan Pendapat Para Ulama. Bandung: Mizan

Hasan Kamil. 1986. Fiqh Ibadah Menurut Mazhab Imam Malik. Mesir: Maktab al- Nahdhah.

Khalaf, Abdul Wahab. 1978. 'IImu Ushul al-Fiqh. Mesir: Dar al-Kalam.

Al-Khudari, Muhammad. 2001. Ushul al-Fiqh, Kairo: Dar al-Hadis.

Hadi Setia Tunggal. 2000. Undang-undang Nomor 38 Tahun 1999 tentang Pengelolaan Zakat. Jakarta: Harvarindo.

Hasballah, Ali. 1959. Ushul al-Tasyric al-Islam. Mesir: Dar al-Macarif.

Muhammad Abdul Qadir Abu Faris. t. th. Kajian Kritis Pendayagunaan Zakat, Semarang:Dina Utama Semarang.

Al-Qaradhawi, Yusuf. 1979 M/1389 H. Fiqh al-Zakat. Beirut: Dar al-Irsa. Cet ke-1.

Qasim, Yusuf. Zakat al-Tijarah wa al-Shanac ah. t.tp.: Dar al-Nahdah

Al-Qurtubi. 1414 H/1996 M. Jamic al-Ahkam al-Fiqh. Beirut: Dar al-Kutub alcIlmiyah.

Rahman , Abdul Malik. 2003. Ibadah Zakat dan Segala Masalahnya, Kuala Lumpur: Jasmin Enterprise..

Sabiq, al-Sayyid. 1414 H/1996 M. Fiqh al-Sunnah. Beirut: Dar al-Kitab al'Arabiyah.

Syechul Hadi Permono. 1995 Pendayagunaan Zakat dalam Rangka Pembangunan Nasional. Jakarta: Pustaka Firdaus.

Al-Sais, Muhammad Ali. 1953. Tafsir Ayat al-Ahkam. Mesir: Matba ${ }^{\mathrm{c}}$ ah Muhammad Ali Sabih wa Auladuhu.

Al-Zuhaily, Wahbah. t. th. Zakat Kajian Berbagai Zakat, Diterjemahkan 
oleh Agus Efendi dan Baharuddin Fananny. Bandung: PT Remaja Rosdakarya Offset.

Al-Zuhaily, Wahbah. 1978. Al-Fiqh al-Islami wa Adillatuhu. Damsik: Dar alFikri. 